\title{
Consolidation characteristics of a thermally cured sand-bentonite mixture
}

\author{
Atena Shirasb ${ }^{1} \cdot$ Amir Hamidi $^{1} \mathbb{D} \cdot$ Mohammad Mehdi Ahmadi $^{2}$
}

Received: 9 February 2020 / Accepted: 19 May 2020 / Published online: 23 May 2020

(c) Springer Nature Switzerland AG 2020

\begin{abstract}
Consolidation behavior of clays and sand-clay mixtures is an important topic in environmental geotechnics, thermal geostructures and disposal of hazardous wastes. The purpose of this paper is investigation of the changes in consolidation behavior of a sand-bentonite mixture due to the pre-curing at elevated temperatures. For this reason, 1:1 mixture of sand-bentonite was used to prepare samples $100 \mathrm{~mm}$ in diameter and $200 \mathrm{~mm}$ in height. The specimens were cured at 40,60 and $80^{\circ} \mathrm{C}$ for 1,3 and 5 days under a constant confining pressure in a modified thermal triaxial cell. Then, consolidation behavior of the prepared samples which have been named as cured samples was investigated. The results show that the cured samples shifted from a reconstituted state to a quasi-structured one. A distinct yield stress was observed in compression curves of cured samples which was not apparent for reconstituted ones. The preconsolidation pressure of cured samples increased with increase in curing temperature and curing time. Also, the coefficient of consolidation and permeability increased as temperature increased, while both values decreased with an increase in curing time. Moreover, a number of specimens were tested under cyclic thermal paths which clearly proved change in behavior of cured samples to a structured one compared to the samples without thermal curing.
\end{abstract}

Keywords Thermal pre-curing $\cdot$ Sand-bentonite $\cdot$ Consolidation $\cdot$ Structure $\cdot$ Curing time

\section{Introduction}

The high temperature underground is an evidence in many energy storage systems, such as hazardous waste disposal, heat exchange piles, aquifer and borehole thermal energy storage systems and high voltage buried transmission where temperature usually varies between 30 and $90^{\circ} \mathrm{C}$, so, the influence of elevated temperature on thermo mechanical behavior of soil is of most of interest in recent geotechnical researches.

One of the first comprehensive studies on consolidation behavior of clays at elevated temperatures has been conducted by Houston et al. [1] on seafloor sediments at a range of temperature from 4 to $200{ }^{\circ} \mathrm{C}$. The results showed that primary thermal consolidation is due to the dissipation of thermally induced pore pressures while the secondary thermal consolidation is due to the weakening intergranular resistance at high temperatures, where this rate increases with increase in temperature.

Thermal consolidation behavior of normally consolidated (NC) clays has been studied in previous studies at temperatures between 25 and $100^{\circ} \mathrm{C}$. Considering compression curves, Abuel-Naga et al. [2] observed a constant slope of NCL for samples at different elevated temperature. It was contrary to the results of Tanaka et al. [3] who reported a decreasing trend for it; however a contractive behavior has been observed for NC clays in both these studies. According to Di donna et al. [4], application of

$\triangle$ Amir Hamidi, hamidi@khu.ac.ir; Atena Shirasb, std_shirasb@khu.ac.ir; Mohammad Mehdi Ahmadi, mmahmadi@sharif.edu| ${ }^{1}$ Department of Civil Engineering, School of Engineering, Kharazmi University, P.O. Box 15719-14911, Tehran, Iran. ${ }^{2}$ Department of Civil Engineering, Sharif University of Technology, Tehran, Iran. 
thermal paths between 5 and $60^{\circ} \mathrm{C}$ changes the behavior of NC samples to an overconsolidated one. The same trend has been reported by Abuel-Naga for temperature cycles of $25-70-25^{\circ} \mathrm{C}$ and $25-90-25^{\circ} \mathrm{C}$. A reduction of elastic domain and increasing softening behavior has also been observed after experiencing thermal loading paths in NC clays.

Thermo-mechanical behavior of Boom Clay, as the host of hazardous radioactive wastes, has also been investigated during heating-cooling cycles between 20 and $100^{\circ} \mathrm{C}$. It has been concluded that the volume change behavior of overconsolidated clays are expansive and dependent to overconsolidation ratio and stress history $[5,6]$. Delage et al. [7] implied a non-expansive behavior for Boom Clay at high temperatures more than $50^{\circ} \mathrm{C}$ that is consistent with the results of Yu et al. [8].

The time dependent behavior of clays has also been evaluated by many researchers previously. According to the results, the soil's behavior changes at low strain rates and high temperatures by increase in preconsolidation pressure due to the increase in the rate of creep $[9,10]$. The thermal hydraulic conductivity of clays has also been evaluated in many works and depends on mineral composition, particle size, dry density, water content, porosity, the degree of saturation the numbers of freeze-thaw cycles [11]. For sand-bentonite mixtures in buffer of radioactive waste disposals, the thermal conductivity of material is an important factor for selecting the appropriate proportion of sand- bentonite mixture which depends on dry density, water content and the sand amount added to bentonite [12]. Although it has been observed that permeability increases with temperature $[13,14]$. Finally, considering the results of experimental studies, thermal constitutive models have been developed to analyze the response of thermal geostructures during temperature application [15-18].

In many cases, clay mixtures are exposed to elevated temperatures for a long period of time, for example, buffer layer of high-level radioactive wastes, thermal energy storage systems and electricity buried cables. As a result, time dependent behavior of these soils is of importance and many researchers have considered the effect of strain rate on the creep behavior of clays [19-22].

The soil structure is determined by its fabric and intergranular forces. It usually results in more strength and more brittleness of soil. A number of previous studies have revealed the effects of creep and temperature on structuring of clays. Many researchers implied that creep occur quickly as temperature increases $[23,24]$. High temperature induced in thermal geostructures during long time leads to the creep deformations and inducing plastic strains. It can finally change soil's fabrics and consequently induces a quasi-structured type of behavior. The effect of temperature on soil's structure has also been reported in other studies which used scanning electron microscopy (SEM) to prove formation of a new structure at higher temperatures [25]. Moreover, in several studies, the change in volume change behavior due to the increased temperature has been investigated and a quasi-structured type of behavior has been reported [26-28].

The consolidation behavior of clays is dependent to temperature $[2,6,27]$. It is mainly due to the reduction in viscosity of pore fluid, subsequent increase in consolidation coefficient $\left(C_{v}\right)$ and the afterward increase in permeability. Other parameters like preconsolidation pressure, compression and swelling coefficients $\left(C_{c}\right.$ and $\left.C_{s}\right)$ have also been evaluated at higher temperatures. An increase in preconsolidation pressure has been shown with increase in temperature $[2,13,29]$ while a few other studies have reported reduction of preconsolidation pressure in higher temperatures [30]. Some studies obtained constant values of compression and swelling coefficients at elevated temperatures [31] and the others showed these coefficients as temperature dependent variables [2, 32].

Attah and Etim [33] also conducted some index tests on two different thermally cured clays to determine changes in liquid limit (LL) and plasticity index (PI) with curing temperature. The LL values were about 49 and 43 while PI values were 29 and 22, respectively for two clays in ambient temperature. Based on the results, both LL and PI decrease in the temperatures range of $20-80^{\circ} \mathrm{C}$ for clay soils. They attributed the reduction of $L L$ of cured clays to the change in clay size fraction, surface charge and specific surface area of fabrics, dehydration and decomposition of soil particles, changes in mineralogy and variation in macro and microstructure of the soils. The same trend is expected for the studied with an initial LL and PI of 83 and 57, respectively. As stated by Jarad et al. [10], stress-strain behavior of soils is dependent to their mineralogy and consolidation curves of samples with higher plasticity characteristics are more affected by temperature.

Review of previous studies shows that although there are several studies on thermal behavior of soils, the effect of thermal curing has not been considered on consolidation behavior of clays. Indeed, most of the previous researches have investigated the consolidation characteristics of clays without any pre-curing. In present study, a number of experiments have been conducted to determine the volume change behavior of pre-cured sand-bentonite mixture at elevated temperature.

The range of applied temperatures was selected to include different thermal issues such as buffer of high-level waste disposals, energy piles and underground buried power cables. The design temperature for buffer layer of nuclear waste disposals should not exceed $90^{\circ} \mathrm{C}$ due to the losing of swelling properties of clayey material. In many 
Table 1 Physical properties of the base soils

\begin{tabular}{lll}
\hline Characteristics & $\begin{array}{l}\text { Sodium ben- } \\
\text { tonite }\end{array}$ & Silica sand \\
\hline Clay & 68 & 0 \\
Silt & 31 & 2 \\
Sand, $0.06-0.2 \mathrm{~mm}$ & 1 & 23 \\
Sand, $0.2-1 \mathrm{~mm}$ & 0 & 55 \\
Sand, $1-2 \mathrm{~mm}$ & 0 & 9 \\
Sand $>2 \mathrm{~mm}$ & 0 & 11 \\
Liquid limit & 179 & - \\
Plasticity index & 125 & $\mathrm{NP}$ \\
Specific surface area $\left(\mathrm{m}^{2} / \mathrm{g}\right)$ & 400 & - \\
Specific gravity & 2.76 & 2.57 \\
Soil's name (USCS) & $\mathrm{CH}$ & $\mathrm{SW}$ \\
\hline
\end{tabular}

cases, high temperature of high-level wastes is reduced before burring in high depths [34]. In Europe, energy piles are designed for temperatures of -1 to $35^{\circ} \mathrm{C}$. However, in some situations, an increase in the temperature up to $40{ }^{\circ} \mathrm{C}$ or $50^{\circ} \mathrm{C}$ is conceivable [35]. For the underground buried power cables, the maximum temperature has been reported about $80^{\circ} \mathrm{C}$ around the cable and $60^{\circ} \mathrm{C}$ for $0.25 \mathrm{~m}$ far from the cable [36].

The pre-curing process was performed by heating the specimens at a constant temperature for a specified time. Based on the results of experiments, the differences between consolidation behavior of reconstituted and cured sand-clay mixtures have been investigated.

\section{Testing procedure}

In this study, a 1:1 mixture by weight of silica sand and sodium-based bentonite with a plasticity index of $125 \%$ has been chosen due to the minimum porosity of mixture as recommended by other researchers [37]. Poorly graded fine sand from the Semnan province of Iran was involved as the coarse-grained part of the mixture. The physical and mineral properties of applied sand and bentonite are given in Tables 1 and 2. Physical properties of sand-bentonite mixture are also depicted in Table 3 and gradation curve of the mixed soil is shown in Fig. 1. A 1:1 combination of sand and bentonite has been mixed in an optimum water content of $21.4 \%$ and compacted in eight equal layers to form a cylindrical specimen with the dry density of $15.3 \mathrm{kN} / \mathrm{m}^{3}$ and relative compaction of $90 \%$.

Various weight ratios of bentonite to sand have been recommended in different studies. For example, in a study of gas migration through saturated bentonite-sand mixtures, Liu et al. used a 3:7 weight ratio for
Table 2 Mineral properties of the base soils

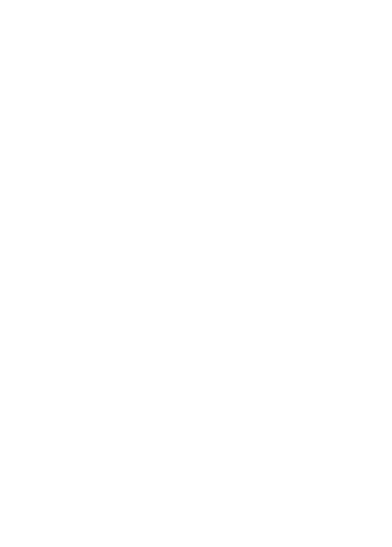

Table 3 Characteristics of 1:1 mixture of sand-bentonite

\begin{tabular}{ll}
\hline Characteristics & Result \\
\hline Soil's name (USCS) & $\mathrm{CH}$ \\
Clay (\%) & 34 \\
Silt (\%) & 16 \\
Sand (\%) & 50 \\
LL (\%) & 83 \\
PI (\%) & 57 \\
$\mathrm{~W}_{\text {opt }}(\%)$ & 21.4 \\
$Y_{\max }\left(\mathrm{kN} / \mathrm{m}^{3}\right)$ & 17.0 \\
\hline
\end{tabular}

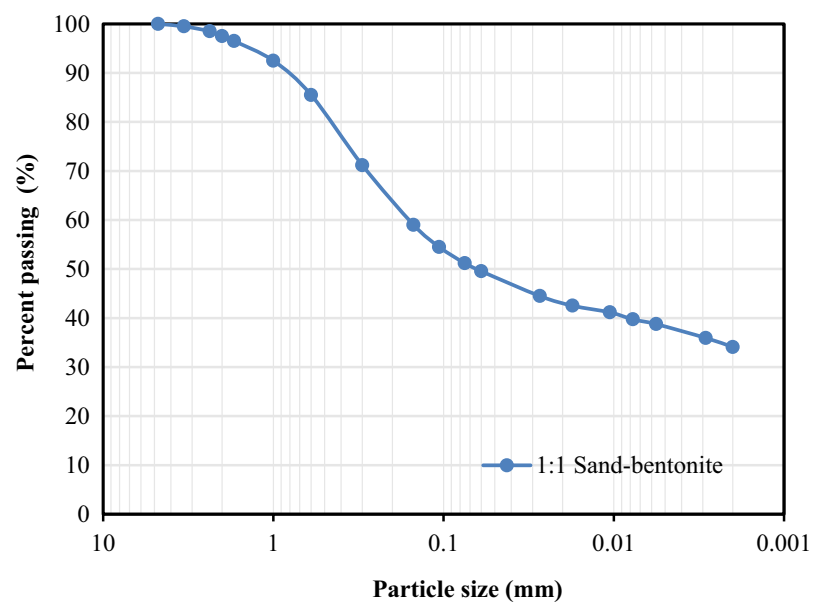

Fig. 1 Particle size distribution curve of sand-bentonite mixture

sodium bentonite to silica sand fractions to achieve the least water permeability [38, 39]. Dixon et al. [37] also defined a parameter named effective porosity $\left(n_{\text {eff }}\right)$ to determine the optimum weight ratio of bentonite to sand in buffer layers according to Eq. (1). 
$\mathrm{n}_{\text {eff }}=1-\rho_{\mathrm{d}} \times\left(\frac{1}{\mathrm{G}_{\mathrm{s}, \text { mix }}}+\frac{0.15 \times F}{1+F}\right)$

Here, $\rho_{d}$ is the maximum dry density, $G_{s, \text { mix }}$ is the specific gravity of mixture and $F$ is weight ratio of clay to sand fractions. In present study, $n_{\text {eff }}$ was calculated for different proportions of sand to bentonite as shown in Fig. 2. According to the figure, minimum effective porosity occurs in 1:1 weight mixture and so, it was selected. This ratio has been also implemented in other recent experimental studies on thermal characteristics of sand-bentonite mixtures [40].

Samples $100 \mathrm{~mm}$ in diameter and $200 \mathrm{~mm}$ in height were prepared for consolidation tests in a thermal triaxial cell. Thermal consolidation tests were performed in a high pressure temperature controlled metallic cell. The specimens were heated using a spiral heater around them which was able to induce temperatures up to $90^{\circ} \mathrm{C}$. A thermocouple with a precision of $\pm 0.1{ }^{\circ} \mathrm{C}$ was placed inside the triaxial cell to control temperature variations. Two windows were also installed on the metallic cell to show the specimen during heating and loading. Volume changes during isotropic consolidation were measured using a sensor with a precision of $0.01 \mathrm{~mL}$. Figure 3 shows the schematics of thermal triaxial cell which has been used in present research.

According to Black and Lee [41], $B$-values between 0.93 and 0.9988 lead to saturation degrees of $99-100 \%$ which take place in 5, 30 and 200 days using a back pressure of $300 \mathrm{kPa}$. Wan et al. [42] achieved a saturation degree of $99.5 \%$ by applying a back pressure of $500 \mathrm{kPa}$ for a sand-bentonite mixture with a liquid limit of $250 \%$ and plasticity index of $200 \%$. Lingnau et al. [43] also received the same degree of saturation using $1000 \mathrm{kPa}$ back pressure for sand-bentonite mixtures with the same plasticity and $50 \%$ clay content. Mollins [44] saturated a

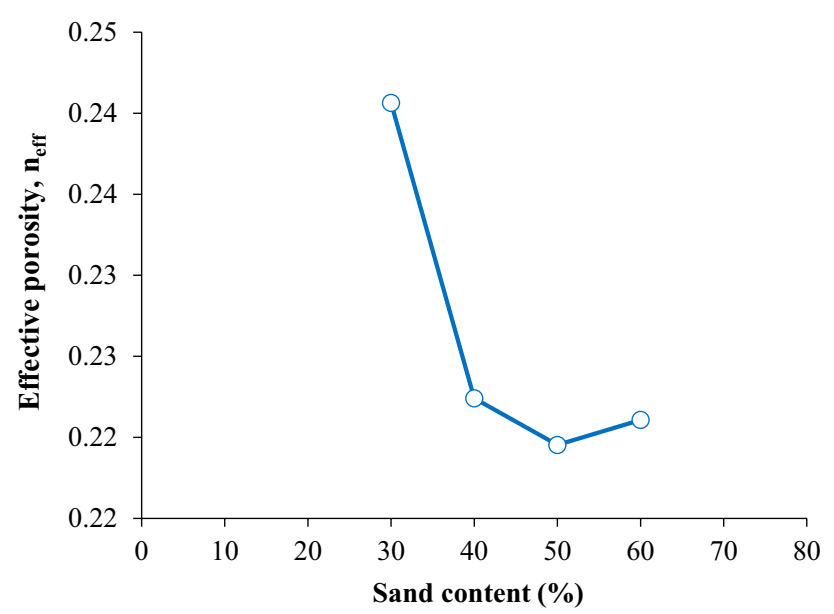

Fig. 2 Variations of effective porosity with sand content in mixtures sand-bentonite mixture with a liquid limit of $407 \%$ and plasticity index of $359 \%$ applying back pressure of $300 \mathrm{kPa}$ in 2 months assuring a $B$-value of 0.98 . Also, $B$-value of 0.93 was obtained by Mukherjee and Mishra [45] inducing back pressures of 480-565 kPa in 12-17 days for sand-bentonite samples with $10 \%$ and $20 \%$ clay content $(L L=286 \%)$, respectively. The coefficient of saturation depends on many factors such as clay content, plasticity characteristics, sample size, back pressure and time of saturation. Based on the previous studies, lower liquid limit $(L L=83 \%)$ and plasticity index $(\mathrm{PI}=57 \%)$ of the mixture used in present study, a back pressure of $700 \mathrm{kPa}$ has been applied in a step by step procedure by increasing the confining pressure and keeping it near to the back pressure which resulted in a Skempton's $B$-value of 0.95 in 6 days.

A number of consolidation tests performed on reconstituted samples without any curing process and some other tests conducted on pre-cured specimens. In order to pre-cure a sample, it was consolidated in a low confining pressure of $20 \mathrm{kPa}$ at temperatures of 40,60 or $80^{\circ} \mathrm{C}$ for 1,3 or 5 days. The liquid limit of $83 \%$ and plasticity limit of $57 \%$ of mixture resulted in a low swelling pressure about $20 \mathrm{kPa}$ based on the empirical relations proposed by Erzin and Erol [46] for the studied soil. The temperature equilibrium inside the specimen has been estimated about $100 \mathrm{~min}$. After thermal curing, confining pressure has been increased up to $1000 \mathrm{kPa}$ at constant temperature and volume change behavior of cured sample was recorded.

Figure 4a shows the required time to complete primary consolidation of the samples $\left(t_{100}\right)$ as the intersection of a tangential line at the inflection point of the consolidation curve at axial strain-log time space and the tangential line at the final part of the curve. The resulted values are shown in Fig. $4 \mathrm{~b}$ for different temperatures and confining pressures. The results show that primary consolidation time increases with temperature and confinement due to the more generated pore water pressure. Accordingly, $t_{100}$ was less than $24 \mathrm{~h}$ for all temperatures in $100 \mathrm{kPa}$. When the confining pressure increased to $500 \mathrm{kPa}$, it was achieved in less than $24 \mathrm{~h}$ at 20,40 and $60^{\circ} \mathrm{C}$. At $1000 \mathrm{kPa}$, it was less than $24 \mathrm{~h}$ only at $20^{\circ} \mathrm{C}$ and $40^{\circ} \mathrm{C}$. However, it was less than $40 \mathrm{~h}$ for all temperatures and confinements. In this regard, the pre-curing periods were selected as 1,3 and 5 days in present study.

Furthermore, another group of tests was planned to study the volume change behavior of cured samples under cyclic thermal loading paths. At one of these paths, temperature cycles were applied to the specimens that have been previously cured at a temperature of $80^{\circ} \mathrm{C}$ for 1,3 or 5 days under confining pressures of $100 \mathrm{kPa}$ or $500 \mathrm{kPa}$. At the first cycle, the temperature decreased to $40^{\circ} \mathrm{C}$ allowing the sample to swell and then increased again to $80^{\circ} \mathrm{C}$ $\left(80-40-80^{\circ} \mathrm{C}\right)$. Then, temperature decreased to $20^{\circ} \mathrm{C}$ and 
Fig. 3 Schematics of the thermal triaxial cell used in present research

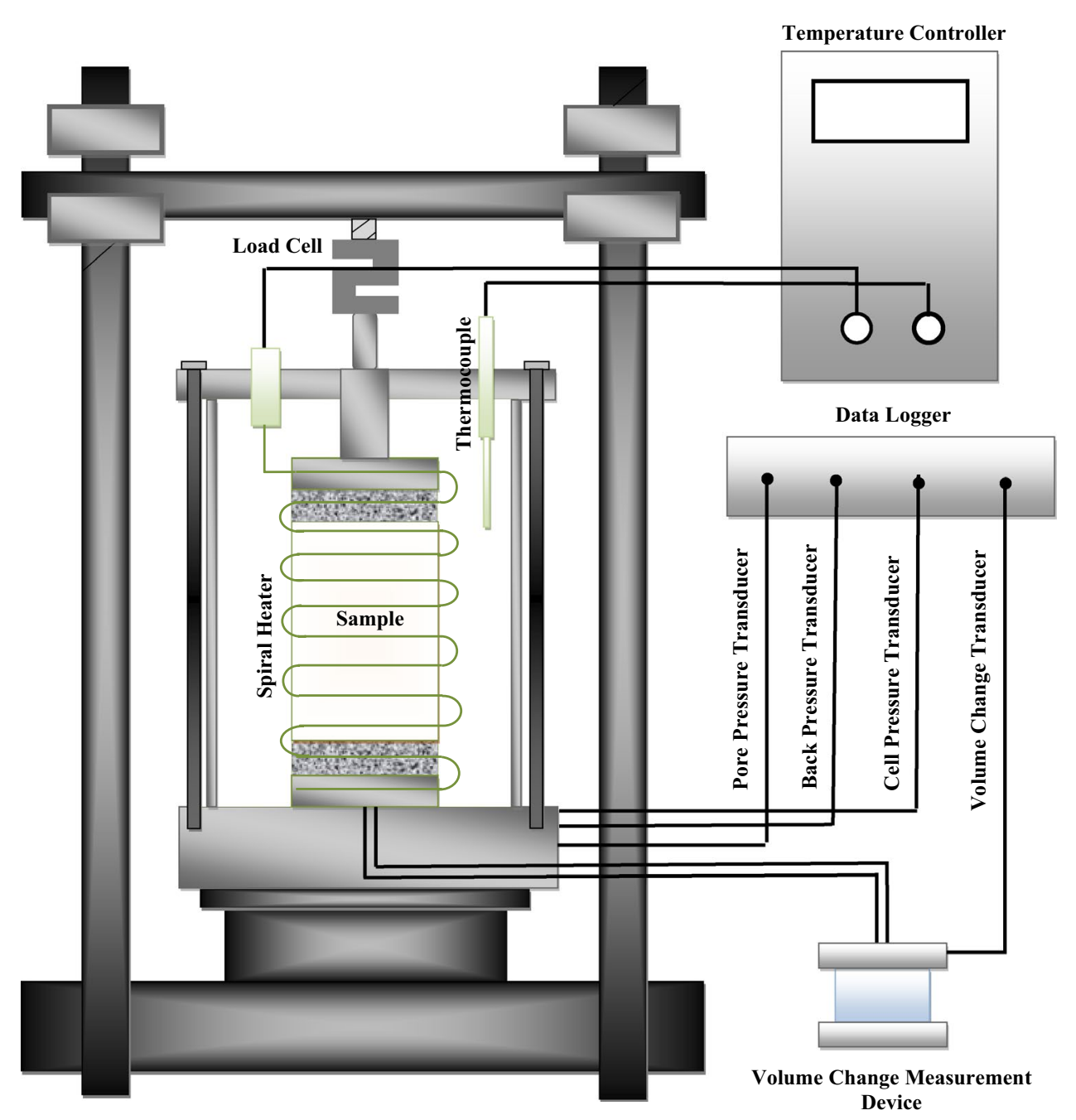

increased again to $80^{\circ} \mathrm{C}\left(80-20-80^{\circ} \mathrm{C}\right)$. For each temperature, the required times for thermal equilibrium and consolidation were accurately allowed up to the volumetric strain values less than $0.1 \%$ /day as recommended in previous studies [43] and the volume change of mixture was exactly measured using a calibrated sensors and data logger system. A summary of testing program is depicted in Table 4.

\section{Results of experiments}

In order to study the effect of curing on consolidation behavior of sand-bentonite mixture, the normal compression lines (NCLs) of reconstituted and cured samples at the ambient $\left(20^{\circ} \mathrm{C}\right)$ and elevated temperatures of $40^{\circ} \mathrm{C}, 60^{\circ} \mathrm{C}$ and $80^{\circ} \mathrm{C}$ are depicted in $v-L n p^{\prime}$ plane (where, $v$ is the specific volume and $p^{\prime}$ is the mean effective stress during consolidation) in Figs. 5 and 6, respectively.
For the pre-cured samples, however, a distinct yield point can be observed on the compression curves as shown in Fig. 6. For these group of samples, temperature increased to elevated values at $20 \mathrm{kPa}$ and after thermal equilibrium, remained constant for 1, 3 or 5 days. Then, consolidation proceeded with step by step increase in confining stress up to $1000 \mathrm{kPa}$ at constant temperature. The mentioned yield points have been defined previously as the virgin yield stress to model the consolidation behavior of structured clays [47]. After yielding, a sudden decrease in void ratio was observed for thermally cured samples. Curing at higher temperatures for more times caused the cured samples to move to higher void ratios in compression plane. A similar trend of behavior has been reported by other researchers for the stiff or artificially structured clays [48-50].

It can be inferred that the behavior of sand-bentonite mixtures experiencing higher temperature shifts to a quasi-structured one. A similar trend of behavior has been observed for a marine clay at a curing temperature of $75^{\circ} \mathrm{C}$ 

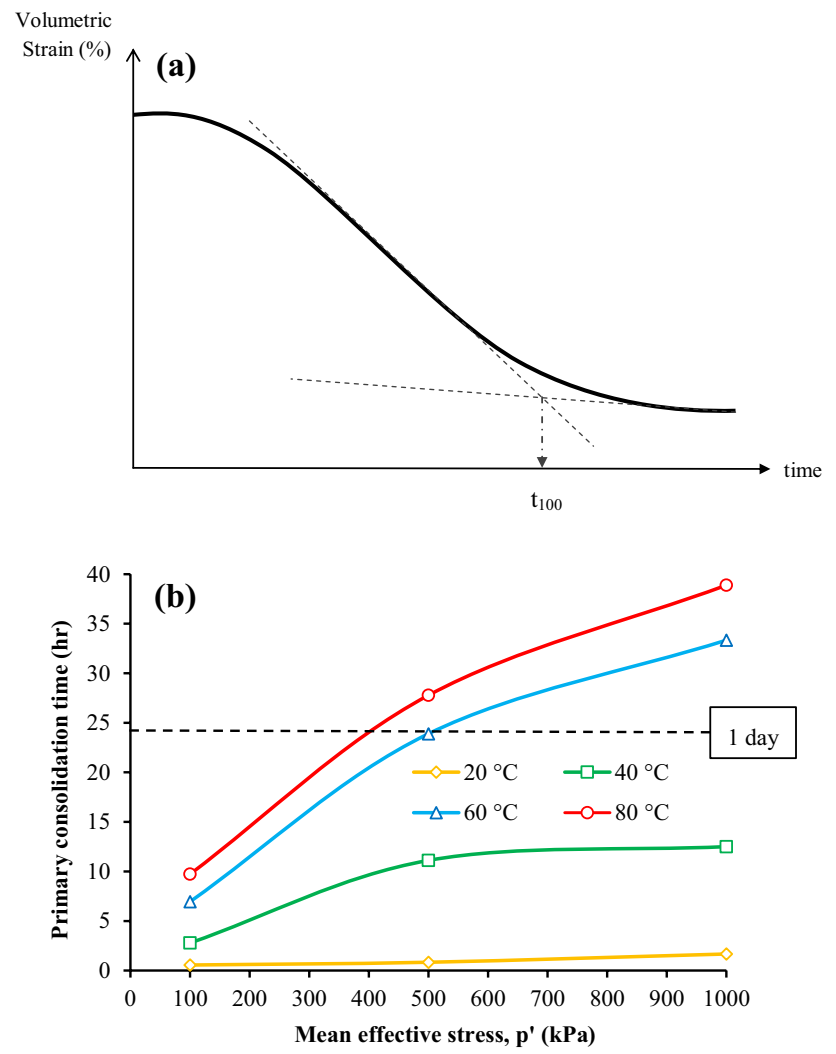

Fig. 4 The required time for the end of primary consolidation. a Determination of $t_{100}$ from consolidation curves, $\mathbf{b}$ required time for primary consolidation at different temperatures and confinements

[26] and $\mathrm{MC}$ clay heated at $90^{\circ} \mathrm{C}$ under a confining pressure of $160 \mathrm{kPa}$ for different periods of time which showed formation of a secondary structure [32] or thermal aging of soil due to the accelerated secondary consolidation as a result of heating as shown in Fig. 7.

According to Figs. 6 and 7, thermally cured samples behave similar to structured soils. Different curing times and curing temperatures lead to different yield stresses. It proves that experiencing pre-curing as a kind of thermal history results in an overconsolidated type of behavior. Thermal dependency of the yield stress has been also indicated by many other researchers [26-28]. According to Tsuchida et al. [26], the main cause of high temperature consolidation is accelerating the structuring action in marine clay of Japan. On the other hand, a quasi-structured type of behavior induces in high temperatures due to the changes in mineralogy which influences the virgin yield stress of clay soil. Moreover, the data presented in Fig. 6 for different consolidation times confirms an increase in virgin yield stress with increase in curing time. This is consistent with results of other researchers stated that the creep in soils results into an apparent increase in preconsolidation stress [21]. The Variations in virgin yield stress with curing time and curing temperature is shown in Fig. 8.

Based on these data, the following empirical equation can be proposed to calculate $p_{y}^{\prime}$ as a modified version of previously developed formula [50], with a regression coefficient of 0.92 based on variations of curing time $(t)$ and curing temperature $(T)$ for an applied confinement of $p_{0}^{\prime}$ :

$\frac{p_{y}^{\prime}}{p_{0}^{\prime}}=\left[1-\alpha \ln \left(\frac{T}{T_{A}}\right)\right]\left[1+\beta \ln (m t)^{\omega}\right]$

In this equation, $T_{A}$ is the ambient temperature and $\alpha, \beta$ and $m$ are parameters that can be found based on calibration by experimental data. For the studied soil, the values have been determined as $0.2,21$ and 45 , respectively. Also, $\omega$ is a temperature dependent parameter introduced as follows [17]:

$\omega=1-\exp \left[\chi\left(1-\frac{T}{T_{A}}\right)\right]$

Here, $\omega$ decreases with increase in temperature based on another parameter, $\chi$. The value of $\chi$ was determined as 0.14 for the studied sand-bentonite mixture based on calibration.

The variations of consolidation coefficient $\left(C_{v}\right)$ and permeability $(K)$ with temperature have been obtained as drawn in Fig. 9a, b, respectively.

The permeability has been obtained according to the following equations from consolidation tests.

Table 4 Experimental program in present work

\begin{tabular}{|c|c|c|c|c|c|c|}
\hline Test group & Purpose & $\begin{array}{l}\text { Num- } \\
\text { ber of } \\
\text { tests }\end{array}$ & $\begin{array}{l}\text { Curing } \\
\text { pressure } \\
(\mathrm{kPa})\end{array}$ & $\begin{array}{l}\text { Curing tem- } \\
\text { perature } \\
\left({ }^{\circ} \mathrm{C}\right)\end{array}$ & $\begin{array}{l}\text { Curing } \\
\text { time } \\
\text { (Days) }\end{array}$ & $\begin{array}{l}\text { Consolidation } \\
\text { temperature }\left({ }^{\circ} \mathrm{C}\right)\end{array}$ \\
\hline 1 & $\begin{array}{l}\text { Studying the compression curves of reconstituted samples at } \\
\text { elevated temperature }\end{array}$ & 4 & - & - & - & $20,40,60,80$ \\
\hline 2 & $\begin{array}{l}\text { Studying the compression curves of cured samples at } \\
\text { elevated temperature }\end{array}$ & 9 & 20 & $40,60,80$ & $1,3,5$ & $40,60,80$ \\
\hline 3 & $\begin{array}{l}\text { Investigating the compression curves of cured samples dur- } \\
\text { ing cyclic thermal paths }\end{array}$ & 5 & 100,500 & 80 & $1,3,5$ & $80-40-80-20-80$ \\
\hline
\end{tabular}




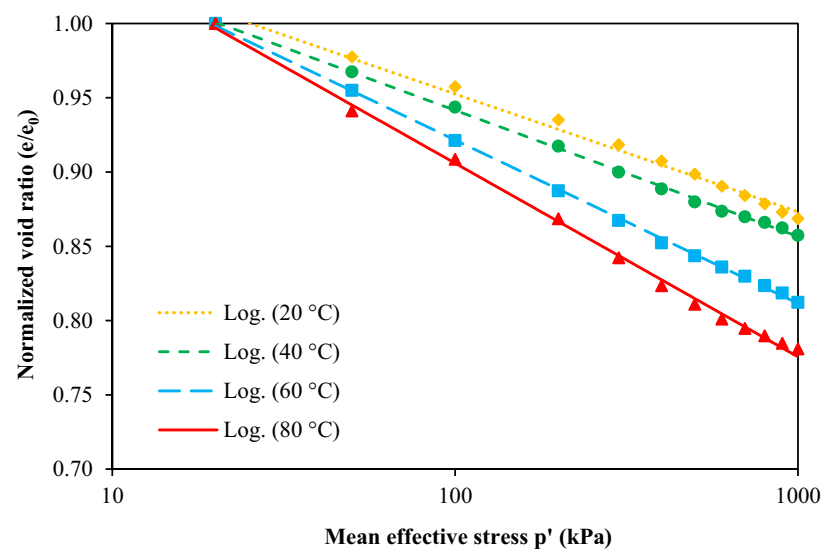

Fig. 5 Compression behavior of reconstituted sand-bentonite mixtures at different temperatures

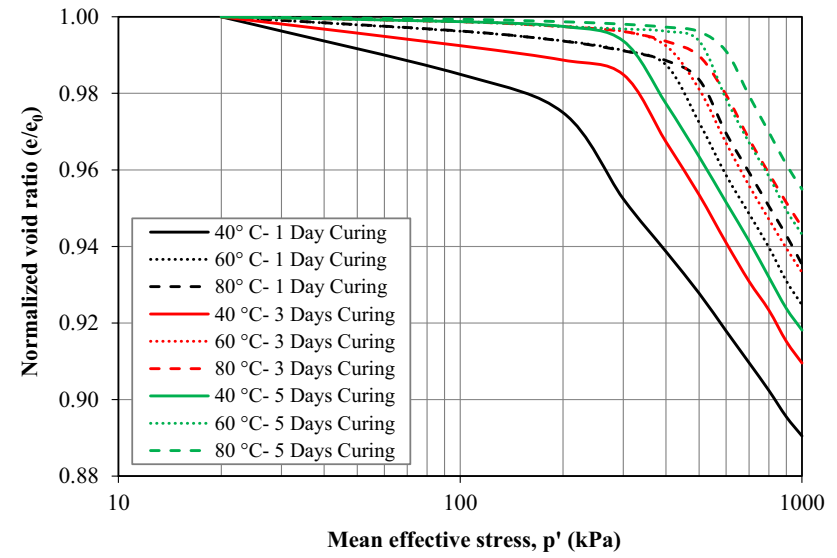

Fig. 6 Compression behavior of thermally consolidated sand-bentonite mixtures cured for 1,3 and 5 days at 40,60 and $80^{\circ} \mathrm{C}$ a $40{ }^{\circ} \mathrm{C}$, b $60^{\circ} \mathrm{C}, \mathrm{c} 80^{\circ} \mathrm{C}$

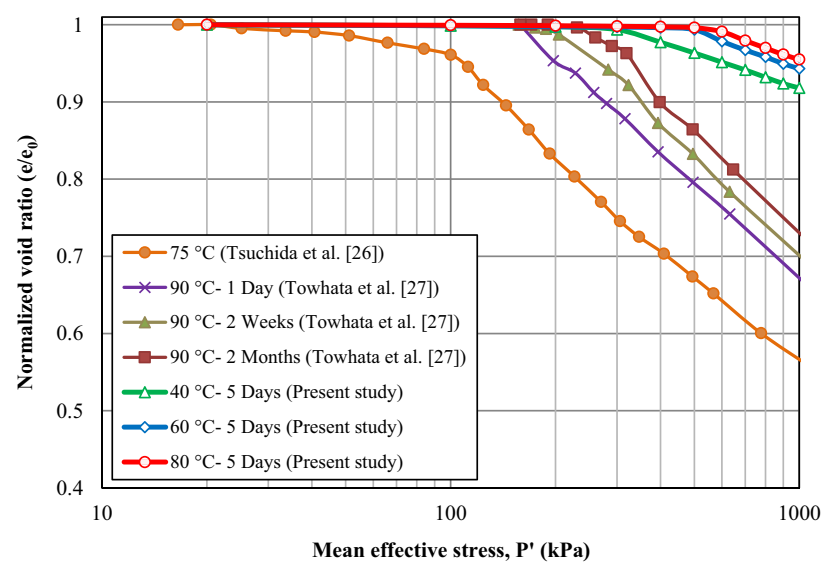

Fig. 7 Comparison of compression curves in present study for 5 days of curing with previous works

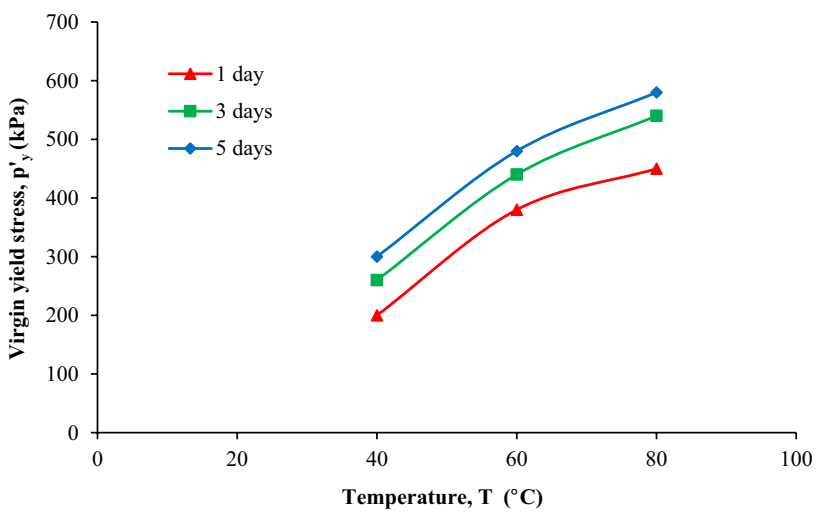

Fig. 8 Variation of the yield stress with curing time and curing temperature
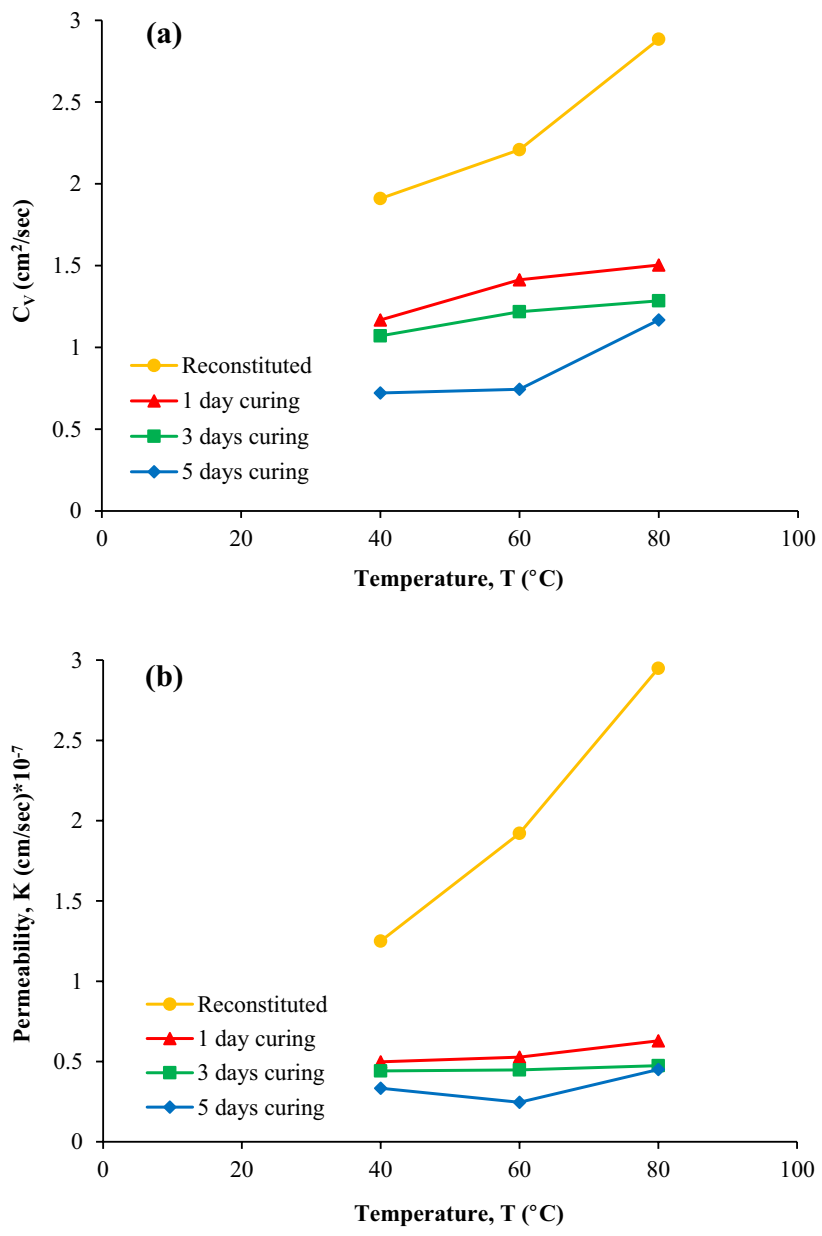

Fig. 9 Variations of the consolidation characteristics of the reconstituted sample with temperature. a Coefficient of consolidation, $\mathbf{b}$ coefficient of permeability 
$C_{v}=\frac{0.848 H^{2}}{t_{90}}$

$K=C_{v} m_{v} \gamma_{w}$

$m_{v}=\frac{\Delta e / \Delta p}{1+e_{0}}$

where $H$ is the length of drainage path, $t_{90}$ is the required time to finish $90 \%$ of consolidation which was obtained from consolidation curves, $\Delta e$ and $\Delta p$ are the changes in void ratio and pressure during consolidation, $m_{v}$ is the coefficient of volume compressibility, $e_{0}$ is the initial void ratio and $\gamma_{w}$ is unit weight of water. As the figures show, increase in temperature increases both the consolidation coefficient and permeability due to the lower viscosity at greater temperatures. This agrees well with the reported experimental results of other studies $[2,6,8]$. However, both values decrease in a pre-cured sample and an increase in curing time decreases $C_{V}$ and $K$ and it can be concluded that the porosity of clayey soil decreases during thermal curing process.

A comparison of hydraulic conductivity values $\left(\right.$ at $20^{\circ} \mathrm{C}$ ) of various 1:1 sand-bentonite mixtures applied in different studies has been shown in Fig. 10 [51-54]. Based on the figure, permeability decreases with increase in plasticity index of bentonite. Also, there is a good agreement between permeability values determined by direct and indirect methods. Gueddouda et al. [55] measured permeability of an unsaturated sand-bentonite mixture $(85 \%$ sand and $15 \%$ bentonite) using direct and indirect methods. Based on the results, although the direct method showed permeability values more than the indirect one, both values merged together at effective mean pressures more than $500 \mathrm{kPa}$.

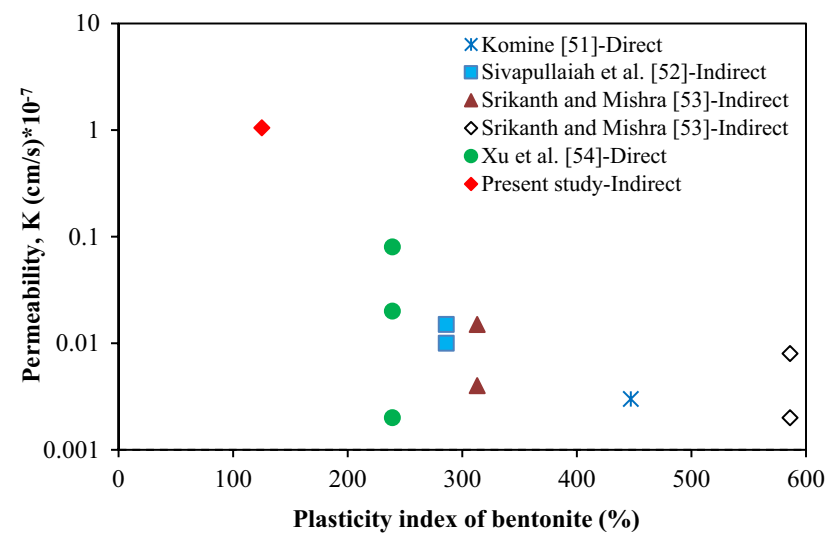

Fig. 10 Variation of permeability for different 1:1 sand-bentonite mixtures in $20^{\circ} \mathrm{C}$ with plasticity index of bentonite
The scanning electron microscopy (SEM) technic has been extensively used in studying the microstructure characteristics and pore size distribution of bentonite [39, 56]. According to SEM analysis of Chen et al. [57], some variations occurred in morphology of saturated clays experienced high temperatures of 100,150 and $200{ }^{\circ} \mathrm{C}$ for a time period of $240 \mathrm{~min}$. These changes were characterized by increasing densification and reduction of void ratio. The SEM studies performed by Attah and Etim [33] on clayey sand also revealed that the initial porous structure of soil turns to a dense fragmented one with lower porosity after preheating to $150{ }^{\circ} \mathrm{C}$ for $4 \mathrm{~h}$. This is consistent with the results of present study and confirms reduction of void ratio during thermal curing.

In order to demonstrate the effect of curing process on the structuring of sand-bentonite mixture, a number of specimens were subjected to cycles of thermal paths. For some samples, after curing in $80^{\circ} \mathrm{C}$ for 1,3 or 5 days, the temperature decreased to $40^{\circ} \mathrm{C}$ allowing the sample to swell, and again increased to $80^{\circ} \mathrm{C}\left(80-40-80^{\circ} \mathrm{C}\right)$. Then, the temperature decreased to $20^{\circ} \mathrm{C}$ and increased again to $80^{\circ} \mathrm{C}\left(80-20-80^{\circ} \mathrm{C}\right)$. These thermal paths are shown in Fig. $11 \mathrm{a}$, b. The required times for thermal equilibrium and consolidation were allowed at each cycle of temperature application. Evaporation of the cell water at high temperatures has been compensated automatically by water pump in confining pressure loop. Evaporation and loss of water in volume change system was determined by calibration which was negligible for the range of applied temperatures and times in the tests. Figure 11c, d depict variations in specific volume during application of thermal paths of Fig. 11a, b, respectively. The results confirmed increase in void ratio or specific volume by decrease in temperature. On the other hand, subsequent increase in temperature decreased the void ratio in elevated temperatures.

Comparison of Fig. 11c, d shows that the variation in specific volume increases with increase in confining pressures, however, it decreases with the increase in curing time of the samples. The former is in accordance with other experimental results $[16,58]$ for the clay under cyclic thermal loading and the latter confirms formation of a new structure in samples during thermal curing as stated by $[5$, 26-28]. For 5 days of curing, the induced plastic volumetric strains during a cooling and heating cycle $\left(80-20-80{ }^{\circ} \mathrm{C}\right)$ is lower than corresponding value for 1 day of curing. It should be noted that only 3 and 5 days curing were used in $500 \mathrm{kPa}$ because according to Fig. 4, the primary consolidation has not been completed at 1 day.

Indeed, although the temperature for the change in the absorbed water layers and dehydration of the montmorillonite is more than $100{ }^{\circ} \mathrm{C}[23,25]$, it seems that heating to lower temperatures can also induce a quasi-structured 


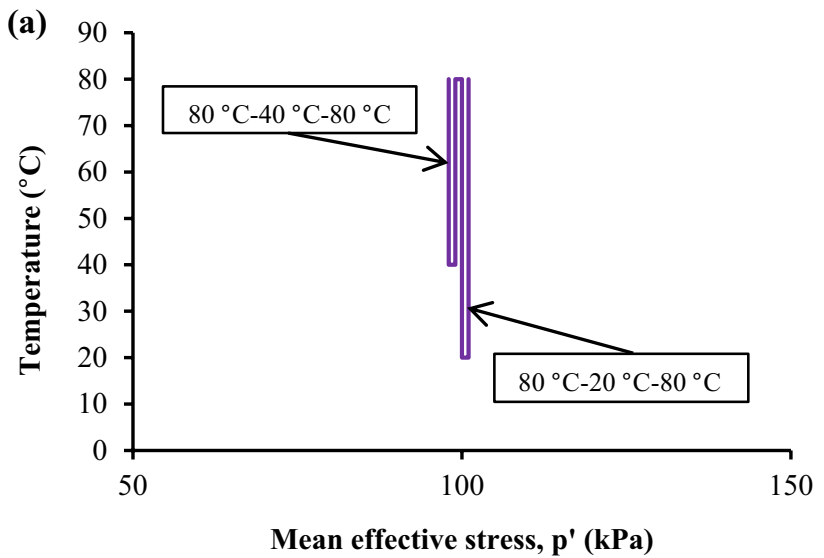

(c)

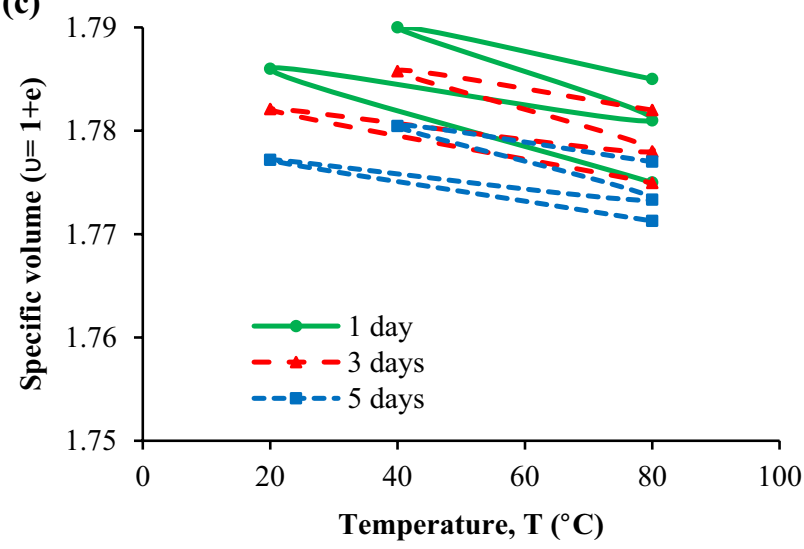

Fig. 11 Application of temperature cycles to the samples. a Thermal paths $\left(80-40-80-20-80^{\circ} \mathrm{C}\right)$ in a confining pressure of $100 \mathrm{kPa}$, b thermal paths $\left(80-40-80-20-80^{\circ} \mathrm{C}\right)$ in a confining pressure of

behavior that increases with curing time and curing temperature.

The figures also indicate that the void ratio does not reach to the initial value after a cycle of cooling and heating. For example, when the soil is cooled from 80 to $20^{\circ} \mathrm{C}$, it swells; however, with further heating to $80^{\circ} \mathrm{C}$, the final void ratio is not equal to the initial value. The induced plastic volumetric strains are smaller for greater curing times and higher curing temperatures. Indeed, the induced structure disturbs during swelling of the soil but the amount of disturbance is less for the samples cured at higher temperatures or greater curing times due to the stronger structure that is formed.

\section{Conclusion}

A testing program has been performed to study the consolidation behavior of a thermally cured sand-bentonite mixture. The samples were initially cured at different times and temperatures. Then, changes in the consolidation
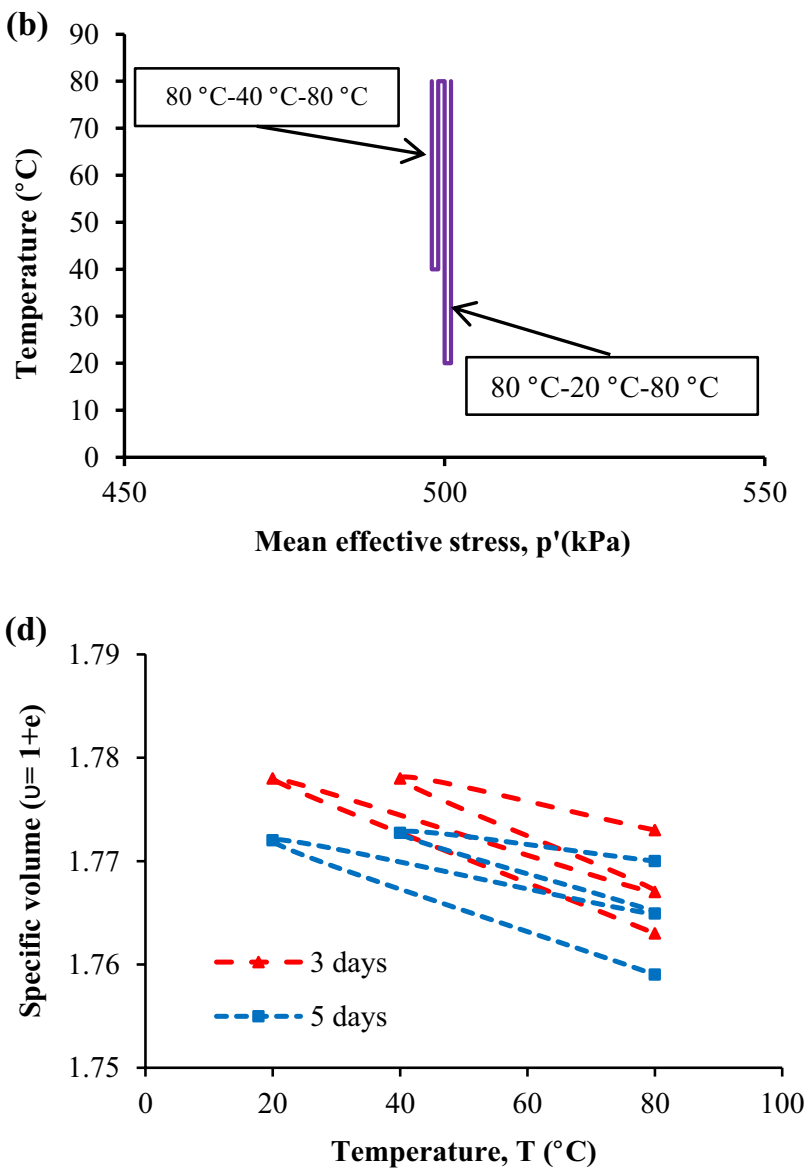

$500 \mathrm{kPa}$, c volume change behavior under thermal path in $100 \mathrm{kPa}$ confinement, $\mathbf{d}$ volume change behavior under thermal path in $500 \mathrm{kPa}$ confinement

behavior have been investigated according to thermal pre-curing. The results of experiments are as follows:

- Although the compression curve of reconstituted sand-bentonite mixture was similar to normally consolidated soils, it was similar to that of overconsolidated or structured soils with a distinct yield stress in thermally pre-cured samples.

- The virgin yield stress in pre-cured mixtures increased as a result of increasing curing temperature and curing time. In this study, an empirical correlation is presented to determine the value of yield stress based on temperature and time of pre-curing.

- The coefficient of consolidation and permeability increased with increase in curing temperature due to decreasing the viscosity of water. However, these values decreased with increase in curing time and curing temperature which was related to the reduction of void ratio during thermal pre-curing process.

- Application of thermal paths including heating and cooling cycles resulted in void ratios different to initial 
value as a result of plastic deformations. The variations in specific volume increased with increase in confining pressure; however, it decreased with increase in curing time. Accordingly, generation of a secondary structure in sand-bentonite mixture was proved during thermal curing process. More investigations are required on the threshold curing temperature and time required to initiate the structuring phenomenon.

\begin{abstract}
Acknowledgements The authors thank all the technicians of Soil Mechanics Laboratory in the School of Engineering of Kharazmi University, Iran. The authors also thank the contribution of Nima Mirmohammadi, the graduate student, who collaborated in setting up the thermal triaxial equipment. Also, the special advises of Enrique Romero and Antonio Gens from UPC, Spain are gratefully appreciated.
\end{abstract}

\section{Compliance with ethical standards}

Conflict of interest On behalf of all authors, the corresponding author states that there is no conflict of interest.

\section{References}

1. Houston SL, Houston WN, Williams ND (1985) Thermomechanical behaviour of seafloor sediments. J Geotech Eng 111:1249-1263

2. Abuel-Naga HM, Bergado DT, Ramana GV, Grino L, Rujivipat $P$, Thet $Y$ (2006) Experimental evaluation of engineering behavior of soft Bangkok clay under elevated temperature. J Geotech Geoenviron Eng 132(7):902-910

3. Tanaka N, Graham J, Crilly T (1997) Stress-strain behavior of reconstituted illite clay at different temperature. Eng Geol 47:339-350

4. Di Donna A, Laloui L (2015) Response of soil subjected to thermal cyclic loading: experimental and constitutive study. Eng Geol 190:65-76

5. Baldi G, Hueckel T, Pellegrini R (1988) Thermal volume changes of the mineral-water system in low-porosity clay soils. Can Geotech J 25:807-825

6. Hueckel T, Pellegrini R (1992) Effective stress and water pressure in saturated clays during heating-cooling cycles. Can Geotech J 29:1095-1102

7. Delage P, Sultan N, Cui YJ (2000) On the thermal consolidation of Boom clay. Can Geotech J 37(2):343-354

8. Yu H, Chena W, Gongc Z, Ma Y, Chen G, Li X (2018) Influence of temperature on the hydro-mechanical behavior of Boom Clay. Int J Rock Mech Min Sci 108:189-197

9. Cui YJ, Le TT, Tang AM, Delage P, Li XL (2009) Investigating the time behavior of Boom clay under thermomechanical loading. Geotechnique 59(4):319-329

10. Jarad N, Cuisinier O, Masrouri F (2017) Effect of temperature and strain rate on the consolidation behavior of compacted clayey soils. Eur J Environ Civ Eng 23(7):789-806

11. Xu X, Zhang W, Fan C, Li G (2020) Effects of temperature, dry density and water content on the thermal conductivity of Genhe silty clay. Results Phys. https://doi.org/10.1016/j.rinp.2019.10283 0
12. Li HF, Chen MQ, Fu BA, Liang B (2019) Evaluation on the thermal and moisture diffusion behavior of sand/bentonite. Appl Therm Eng 151:55-65

13. Romero E, Gens A, Lloret A (2001) Temperature effects on the hydraulic behaviour of an unsaturated clay. Geotech Geol Eng 19:311-332

14. Lee JO, Choi H, Lee JY (2016) Thermal conductivity of compacted Bentonite as a buffer material for a high-level radioactive waste repository. Ann Nucl Energy 94:848-855

15. Graham J, Tanaka N, Crilly T, Alfaro M (2001) Modified CamClay modelling of temperature effects in clays. Can Geotech J 38(3):608-621

16. Cekerevac C, Laloui L (2004) Experimental study of thermal effects on the mechanical behaviour of a clay. Int J Numer Anal Methods Geomech 28:209-228

17. Hamidi A, Khazaei C (2010) A thermo-mechanical constitutive model for saturated clays. Int J Geotech Eng 4:445-459

18. Hamidi A, Toorchi S, Kardooni F (2017) A critical state based thermo-elasto-plastic constitutive model for structured clays. J Rock Mech Geotech Eng 9:1094-1103

19. Graham J, Houlsby GT (1983) Anisotropic elasticity in a natural plastic clay. Geotechnique 33:165-180

20. Leroueil S, Kabbaj M, Tavenas F, Bouchard R (1985) Stressstrain-strain rate relation for the compressibility of sensitive natural clays. Géotechnique 35(2):159-180

21. Leroueil S, Vaughan PR (1990) The general and congruent effects of structure in natural soils and week rock. Géotechnique 40:467-488

22. Mitchell JK, Soga K (2005) Fundamentals of soil behavior. Wiley, Hoboken

23. Burghignoli A, Desideri A, Miliziano S (1992) Deformability of clays under non isothermal conditions. Rivista Italiana di Geotecnica 26:227-236

24. Kaddouri Z, Cuisinier O, Masrouri F (2019) Influence of effective stress and temperature on the creep behavior of a saturated compacted clayey soil. Geomech Energy Environ 17:106-114

25. Pusch R, Guven N (1990) Electron microscopic examination of hydrothermally treated bentonite clay. Eng Geol 28:303-314

26. Tsuchida T, Kobayashi M, Mizukami J (1991) Effect of aging of marine clay and its duplication by high temperature consolidation. Soils Found 31(4):133-147

27. Towhata I, Kuntiwattanaku P, Seko I, Ohishi K (1993) Volume change of clays induced by heating as observed in consolidation tests. Soils Found 33(4):170-183

28. Akagi H (1994) A physico-chemical approach to the consolidation mechanism of soft clays. Soils Founds 34(4):43-50

29. Sultan N, Delage P, Cui YJ (2002) Temperature effects on the volume change behaviour of Boom clay. Eng Geol 64:135-145

30. Mon E, Hamamoto K, Kawamoto S, Komatsu T, Moldrup P (2013) Temperature effects on geotechnical properties of kaolin clay: simultaneous measurements of consolidation characteristics, shear stiffness, and permeability using a modified oedometer. GSTF Int J Geol Sci 1(1):1-10

31. Campanella RG, Mitchell JK (1968) Influence of temperature variations on soil behavior. J Soil Mech Found Div 94:709-734

32. Tsutsumi A, Tanaka H (2012) Combined effects of strain rate and temperature on consolidation behavior of clayey soils. Soils Found 52(2):207-215

33. Attah IC, Etim RK (2020) Experimental investigation on the effects of elevated temperature on geotechnical behaviour of tropical residual soils. SN Appl Sci 2:370. https://doi. org/10.1007/s42452-020-2149-x

34. ANDRA (2005) Dossier 2005, Re'fe'rentiel du site Meuse/Haute Marne, Tome 2, Report CRPADS040022_B. Chatenay-Malabry: ANDRA 
35. Knellwolf C, Peron H, Laloui L (2011) Geotechnical analysis of heat exchanger piles. J Geotech Geoenv Eng 137(10):890-902

36. Oclon P, Taler D, Cisek P, Pilarczyk M (2015) FEM-based thermal analysis of underground power cables located in backfills made of different materials. Strength Mater 47(5):770-780

37. Dixon DA, Gray MN, Thomasa W (1985) A study of the compaction properties of potential clay-sand buffer mixtures for use in nuclear fuel waste disposal. Eng Geol 21:247-255

38. Liu J-F, Song Y, Skoczylas F, Liu J (2016) Gas migration through water-saturated bentonite-sand mixtures, COx argillite, and their interfaces. Can Geotech J 53(1):60-71

39. Liu J-F, Song S-B, Ni H-Y, Cao X-L, Pu H, Mao X-B, Skoczylas F (2018) Research on the gas migration properties in a saturated bentonite/sand mixture under flexible boundary condition. Soils Found 58(1):97-109

40. Shariatmadari N, Saeidijam S (2011) The effect of thermal history on thermo-mechanical behavior of bentonite-sand mixture. Int J Civil Eng 10(2):162-167

41. Black DK, Lee KL (1973) Saturating laboratory samples by back pressure. J Soils Founds 99(I41):75-93

42. Wan AWL, Graham J, Gray MN (1990) Influence of soil structure on the stress-strain behavior of sand-bentonite mixtures. Geotech Test J 13(3):179-187

43. Lingnau BE, Graham J, Yarechewski D, Tanaka N, Gray MN (1996) Effects of temperature on strength and compressibility of sandbentonite buffer. Eng Geol 41:103-115

44. Mollins LH (1996) The design of bentonite-sand mixtures. Ph.D. thesis, University of Leeds, UK

45. Mukherjee K, Mishra AK (2019) Evaluation of hydraulic and strength characteristics of sand-bentonite mixtures with added tire fiber for landfill application liner. J Environ Eng 145(6):04019026

46. Erzin Y, Erol O (2004) Correlations for quick prediction of swell pressures. Electron J Geotech Eng 9(1):476

47. Liu MD, Carter JP (2002) A structured cam clay model. Can Geotech J 39:1313-1332

48. Burland JB, Rampello S, Georgiannou VN, Calabresi G (1996) A laboratory study of the strength of four stiff clays. Geotechnique 46(3):491-514
49. Locat J, Tremblay H, Leroueil S (1996) Mechanical and hydraulic behavior of a soft inorganic clay treated with lime. Can Geotech J 33(3):654-669

50. Shirasb A, Karimi AH, Hamidi A, Ahmadi MM (2019) A critical state constitutive model for the isotropic thermal compression of structured sand-bentonite buffers. Indian Geotech J 49(4):398-408

51. Komine H (2004) Simplified evaluation on hydraulic conductivities of sand-bentonite mixture backfills. Appl Clay Sci 26(1-4):13-19

52. Sivapullaiah PV, Sridharan A, Stalin VK (2000) Hydraulic conductivity of bentonite-sand mixtures. Can Geotech J 37(2):406-413

53. Srikanth V, Mishra AK (2016) A laboratory study on the geotechnical characteristics of sand-bentonite mixtures and the role of particle size of sand. Int J Geosynth Ground Eng 2(3):1-10

54. Xu L, Ye WM, Chen B, Chen YG, Cui YJ (2016) Experimental investigations on thermo-hydro-mechanical properties of compacted GMZ01 bentonite-sand mixture using as buffer materials. Eng Geol 213:46-54

55. Gueddouda MK, Goual L, Benabed B, Taibi S, Aboubekr N (2016) Hydraulic properties of dune sand-bentonite mixtures of insulation barriers for hazardous waste facilities. J Rock Mech Geotech Eng 8:541-550

56. Liu JF, Song SB, Cao XL, Meng QB, Pu H, Wang YG, Liu JF (2020) Determination of full-scale pore size distribution of Gaomiaozi bentonite and its permeability prediction. J Rock Mech Geotech Eng 12:403-413

57. Chen Z, Zhu H, Yan Z, Zhao L, Shen Y, Misra A (2016) Experimental study on physical properties of soft soil after high temperature exposure. Eng Geol 204:14-22

58. Zhou C, Ng CWW (2018) A new thermomechanical model for structured soil. Géotechnique 68(12):1109-1115

Publisher's Note Springer Nature remains neutral with regard to jurisdictional claims in published maps and institutional affiliations. 